\title{
Explain the Determinants of Credit Spreads in the US
}

\author{
Wenqi Zhang \\ Beijing Railway Materials Co., Ltd., Beijing, China \\ Email: 1121278696@qq.com
}

How to cite this paper: Zhang, W. Q. (2021). Explain the Determinants of Credit Spreads in the US. Open Journal of Business and Management, 9, 775-794. https://doi.org/10.4236/ojbm.2021.92041

Received: January 18, 2021

Accepted: March 26, 2021

Published: March 29, 2021

Copyright $\odot 2021$ by author(s) and Scientific Research Publishing Inc. This work is licensed under the Creative Commons Attribution International License (CC BY 4.0).

http://creativecommons.org/licenses/by/4.0/

\begin{abstract}
This paper focuses on how economic variables affect Baa corporate bond spreads in the US from January 1990 to December 2018. Credit spreads in this paper are defined as the Baa corporate bond yield minus the Aaa corporate bond yield, and are explained by four variables which are interest rates, the slope of yield curve, the stock market volatility and the economic environment. Cointegration analysis and VAR model are used in this paper to estimate the effects of the determinants of the credit spreads in the long-run and in the short-run respectively. The impacts of the industrial production index and the slope of yield curve on the Baa credit spread are negative, and the impacts of 10 year Treasury bond rate and the stock market volatility on the credit spreads are positive in the long run. In the short-run dynamic relationship, the impact of the industrial production index and the 10 years Treasury bond interest rate are negative for the credit spreads, and the slope of yield curve and stock market volatility are positive for the Baa credit spreads.
\end{abstract}

\section{Keywords}

Corporate Bond Spreads, Dynamic Relationships, Cointegration, VAR

\section{Introduction}

The US experienced the worst financial crisis since the Great Depression in 2008. The liquidity problem and the credit crunch have caused serious damage to the US economy. During this financial crisis, credit spreads became a key indicator of the degree of tension in the financial system (Simon \& Egon, 2012). This paper explains the US credit spreads forecasting models according to some financial and economic variables. This paper uses the data set of the Moody's US Aaa corporate bond yield and Baa corporate bond yield, and the data used in 
this paper are from January 1990 to December 2018 at a monthly frequency. Because Aaa bonds are considered the highest rated bond, they can almost be regarded as risk-free bonds, so in this paper the Baa credit spreads are defined as the yield of Baa corporate bond minus the yield of the Aaa corporate bond.

By constructing a series of econometric models, try to analyze determinants of credit spreads and the different effects of various factors on credit spreads. This paper is based on previous empirical analysis, such as Morris, Neale and Rolph (1998) and Davies (2004). A key element of this paper is to explore the impact of interest rates on credit spreads. Merton (1974) and Duffee (1998), argued that the risk free interest rate has a negative impact on credit spreads, which means that if the risk free rate increases, the credit spreads will decrease. However, Morris, Neale, and Rolph (1998) concluded that when the risk free rate increases, the credit spreads will widen. This paper will explore how long run and short run the risk free rate affect credit spreads, respectively. And we find that in the long run, the credit spreads have a positive relationship with the risk free rate, and in the short run, the relationship is negative. Other results show that the stock market volatility is positive with the credit spreads, and when the industrial production index increases, the credit spreads will decrease. The result shows that the slope of yield curve affects credit spreads differently in the long run and short run, such as in the long run, it has a negative relationship with the credit spreads, and in the short run, the relationship is positive.

There are a large number of literatures to discuss credit spreads. Pedrosa and Roll (1998) came to the conclusion that different bond index portfolios with different credit ratings, different mature groups of bonds and different industries will have a common change in their credit spreads. Because the theory predicts that the aggregate variables generally affect all credit spreads, such as the risk free rate changes, economic environment changes and the stock market volatility. Collin-Dufresn et al. (2001) also indicated that changes in the aggregate factors of the corporate bond market will lead to changes in credit spreads for most time series. Therefore, this paper will discuss how the aggregate variables affect the credit spreads. In this paper, we use cointegration to model the time-series of the Baa credit spread with the interest rates, VIX index, industrial production index and the stock market volatility. The econometric analysis is conducted using the cointegration approach, which identifies the long-run relationships among variables that determine credit spreads. And this paper will also examine the dynamic relationship of the variables in the US, so we build a VAR model and then analyze the impulse response based on it. We analyze how the variables affect credit spreads when the variable is shocked.

This paper takes a new perspective to explore the determinants of Baa corporate bond spreads. Some literatures use the cross-sectional approach to analyze the influencing factors of credit spreads, and some focus on the credit spreads based on the risk structure of the interest rate. By contrast, we will construct a time-series model. In addition, at present, much analysis used conventional re- 
gression models, and VAR models are used relatively rarely. The use of the VAR model is more able to capture the dynamic changes of variables than the traditional single equation model, so this paper uses the VAR model for dynamic research. Because the conventional regression does not observe the effects of the dynamic variables, so according to traditional research, it is impossible to get a conclusion of how variables affect credit spreads in the long-term and short-term. Although Morris, Neal and Rolph (1998) used the VAR model to analyze the dynamic relationship, they only explained the relationship between the credit spreads and interest rates, we add some other factors that determine the credit spreads. We use the cointegration model to analyze the impact of the variables in the long-run, and then we establish the VAR model to show the short-run relation.

The rest of the paper is organized as follows. In the first part, we examine the theoretical determinants of the credit spreads. The second section is literature review. The third section is data, methodology and results. In this part, we discuss the data and define the proxies we used, and we will analyze our regression result. We conclude in the final part.

\section{Theoretical Credit Spread Models}

The first theoretical model for the impact of default risk on bonds was introduced by Merton (1974), and since then, Merton's basic formulation has been extended and improved. Merton (1974) constructed a default risk model based on the basis of option pricing theory, and his model argued that when an investor buys a risky corporate bond, the value of the bond is equivalent to the investor buying a long term equivalent risk free bond. When selling a put option of the underlying company value, the selling price is equal to the face value of the risk free bond.

After Merton proposed the structural model, many related studies were proposed based on his model, and the model was changed and extended, the factors affecting the default risk bond price in the structural model are different. These factors may be affected by many factors, such as how the threshold of default events is defined, how to regulate the value process of the firm and the cost of bankruptcy. However, for variants of Merton's model, a range of factors that determine the price of default risk bond based on the Merton model are also common.

When the structural model of default risk has empirical relevance, the price determinant of the model is also suitable to explain changes in corporate bond spreads. Because this article does not examine changes in credit spreads at the individual company level, we focus on the Baa credit spreads at the aggregate level, so this article includes variables that represent company-specific factors at the aggregate level.

There are three types of factors which we use to explain the determinants of credit spreads: interest rate related variables, variables related to the economic 
environment and equity related variables. In the following, the variables used in this paper will be described in detail.

1) Changes in the interest rate

The structural model of the credit risk shows that risk free interest rate is related to risk debt pricing. First, Merton (1974) argues that when the risk free rate increases, the present value of the future expected cash flow discount will decrease, thus reducing the price of the put option. The investor of the corporate bond shorts put option, and the value of his long corporate bond position will increase. The increase of the price of the corporate bond will decrease the spread. Second, when we consider the impact of risk free interest rates on credit spreads from the perspective of supply and demand, if interest rates fall, the company may increase the supply of bonds, and the price of bonds will fall accordingly, thus credit spreads will increase. Bevan and Garzarelli (2000) also found through empirical analysis that the risk free interest rate has a negative impact on credit spreads in the short run, and they thought that in the short-term, the specific growth of government bonds will lead to a relatively small increase in corporate bond interest rates.

On the other hand, according to the creditworthiness and risk preference hypothesis, we can find risk free interest rate is positively correlated with corporate bond spreads. According to this hypothesis, when interest rates rise, the debtor's repayment burden increases, which can lead to a decline in their ability to pay and lower their credibility. Moreover, investors may increase their risk exposure to increase the return of their portfolio before generally lowering interest rates. Therefore, investors will increase demand for corporate bonds, which will lead credit spreads to tighten.

2) Changes in the slope of yield curve

The analysis of the yield curve slope comes from two aspects: first, the yield curve slope can represent the expected future risk free rate. Therefore if the yield curve slope increases, the expected future short rate will increase. According to the Merton (1974) framework, a steep slope could tighten the credit spread because of the expected rise in the risk free rate.

From the economic environment perspective, when the yield curve declines, the economy may be in a period of weakness. When the economy is in recession, expected recovery rate may fall. Fama and French (1989) argued that when the economy is in recession, credit spreads will increase. Therefore, when the slope of yield curve is shallow, the yield of corporate debt will be higher, and the corporate bond spreads will increase.

3) Changes in the economic environment

We take monthly growth rates in the US industrial production index in percent as a measure of the state of the economic conditions. On the one hand, the increase in industrial production indicates an upward trend in the economy, which means that the enterprise asset value will increase, and the leverage ratio of the firm will decline, and corporate bond default rates decline, thereby reduc- 
ing credit spreads. On the other hand, when the industrial price index rises, it means a better economic environment. When a bond default occurs, the potential recovery rate will have a higher expected value when the economic environment is favourable. Therefore, increases in the business cycle will decrease the credit spreads.

4) Changes in the volatility of the stock market

According to the structural models, volatility in the company value can affect credit spreads. Merton (1974) finds that equity volatility increases the spread of default risk. If the volatility of the underlying asset rises, investors may be more likely to exercise put options, so the price of the option will increase. For the time being, large changes in leverage are likely to occur with higher volatility. Therefore, the leverage ratio is likely to tend to be unified, or the company value may be lower than the debt face value, and the probability of the default of the firm will increase. This article does not analyze the leverage ratio, so we will use an appropriate index to represent the stock market volatility. We will expect that when the volatility of stock market rises the credit spreads will widen.

\section{Literature Review}

There are a large number of literatures on credit spreads, which are broadly divided into three areas. Some literatures use the cross-sectional approach to analyze the influencing factors of credit spreads, and some analysis the credit spreads based on the risk structure of the interest rate, and some focus on the valuation of risky debt.

A lot of literatures focused on the issue of bonds in individual companies. Duffee (1998) analyzed a sample of non-callable bonds, and he concluded that the interest rates are negatively correlated with the credit spreads, but the relationship is weak. Yield spreads on investment-grade non-callable bonds fall when the three month Treasury bill yield rises. His analysis of credit spreads relies on a simple VAR approach. He found that if the government bonds yields rise, the corporate bond spreads will be greatly reduced, and Longstaff and Schwartz (1995) found the similar conclusion, which they thought if the government bonds rate rises, the value of the company's assets will fall, and the bond spread will decrease. Collin-Dufresn et al. (2001) analyzed the determinants of credit spreads from a contingent-claims or no-arbitrage perspective, and they argued that the credit spreads are caused by two factors, one is the default risk of the bond, and the other is that the bondholder can only get a part of the payment when the default occurs. This article explores the influencing factors of changes in individual industrial bond spreads. They found that the main factor affecting changes in corporate bond spreads is the change in supply and demand in the local market. Moreover, their conclusion is opposite to the predictions of structural models of default, they found that when studying the influencing factors of credit spread changes, common factors may be more important than company-specific factors, and this is the opposite of the prediction of 
the default structure model.

Avramov et al. (2007) used a linear time-series regression, they explored the change in credit spreads also based on a default risk structure model and studied the impact of variables on individual corporate bond spreads. They conducted time series regression and found that the results of the regression can well support the structural model. In terms of changes in individual credit spreads, the common factor can explain about $44 \%$, while the company-level factor can only explain $26 \%$, which implies that the common factors are more important than the firm level factors, and the conclusion is the same as Collin-Dufresn et al. (2001).

Morris, Neale and Rolph (1998) argued that the corporate rates are cointegrated with interest rates. They showed that in the short term, a rise in the government bonds rates will decrease the corporate bond spreads, and it will increase the credit spreads in the long run. Bevan and Garzarelli (2000) also came to the conclusion that interest rates have a negative relationship with credit spreads in the short term. Moreover, Morris, Neale and Rolph (1998) found that the Baa spreads are more sensitive compared with the Aaa spreads when the risk-free rate changes. Moreover, Manzoni (2002) considered supply and demand, and he argued if the risk free rate decreases, the supply of the corporate bond will increases, therefore, the price of the bond will decrease, and the credit spreads will widen. Bevan and Garzarelli (2000) also used the cointegration approach to study how economic variables affect corporate bond spreads. They use real GDP to represent the economic environment, and explore its relationship with credit spreads. They found that better economic environment will make credit spreads smaller. They also studied how volatility in the stock market affects the corporate spreads, and in their analysis, when the volatility of the stock market increases $5 \%$, the credit spread will increase $25 \mathrm{bp}$.

Elton et al. (2001) used the time series and cross-sections to analysis the corporate bond spreads which they defined the credit spread as the difference between the yield of the corporate bond and the government bonds, and they found that the systematic risk factors related to equity expected return are very important when analyzing the credit spreads. They use the cross-sectional regression to show that the most important factors for determining the corporate bond spread are the market factors of the stock market returns. The results of the econometric model seemed to be the opposite of the structural model. After Merton (1974) proposed the structural model, a series of studies were carried out on his basis, and the structural model of corporate bond yields showed that the liabilities of the company were considered to be contingent claims on the underlying value of company. The structural model of corporate bond yields means that when pricing corporate bonds, it should not be based on the expected return on the underlying assets, because if pricing takes this factor into account, investors may hedge the risk through replication. This means that when we consider all the variables related to bond prices, the price of the expected return 
bond on the underlying asset and the systemic risk affecting the underlying asset price are independent of the bond prices.

Davies (2007) used data covering 85 years of history, which included many different business cycles. He used the cointegration approach to explain that the relationship between the risk-free interest rate and the slope of the yield is positively related to the credit spread. Moreover, he used the regime switching econometric techniques, and divided two regimes, such as inflationary period and deflationary period. He found that both in the long-term and short-term, the performance of the stock market seems to be the key factor in determining the changes in credit spreads, and the credit spread of low grade bonds is more dependent on the current economic environment than the higher grade spreads. He found that in a deflationary economic environment, when risk-free interest rates change, bonds with low credit ratings are 10 times more sensitive than in an inflationary economy.

Idiosyncratic volatility and liquidity are the two main factors of Kalimipalli et al. (2013) concern, and the VAR model is constructed to explore its dynamic relationship with changes in credit spreads. They conduct portfolio based on Collin-Dufresn et al. (2001) model, and they concluded that idiosyncratic volatility and illiquidity have the greatest impact on low-rated bonds compared to high-rated bonds. They built VAR models to analyze how volatility and liquidity affect corporate bond spreads, and they found the impact of volatility shocks on credit spreads is more durable and will continue to have a positive effect, but the impact of liquidity shocks will disappear in the long run. Campbell and Taksler (2003) also focused on how the volatility of the stock affects corporate bond spreads, and they used the panel data found that when the volatility of equity increase, the credit spreads will widen.

Krishnan et al. (2010) found that when predicting credit spreads at the company level, the information contained in the shape of the credit spread curve is very helpful for this prediction, and they found that even the same bonds, as long as the maturity of the bonds are different, their credit spreads will behave differently.

Tao-Hsien and Kemeth (2005) studied the extent to which stock market factors affect spreads when interpreting cross-sectional changes in corporate bond spreads. They point out that although the changes in credit spreads are largely influenced by factors of the systematic Fama-French, the additional explanatory power of the Fama-French model is very limited when we keep the variables associated with defaults constant.

Anderson and Sundaresan (1996) and Eom et al. (2004) have recently studied the changes in credit spreads based on structural models. Anderson and Sundaresan (1996) used data from the US bond market to compare several different structural models. They found that models using endogenous bankruptcy barriers are more suitable for US bond data than Merton (1974) models. Eom et al. (2004) tested another structural model with cross-section data from 1997. 
They found that it is possible to underestimate the yield of the corporate bond when using Merton (1974) model. However, it tends to overestimate the yield of corporate bond when using Longstaff and Schwartz (1995).

Longstaff and Schwartz (1995) used time series regression to study short-term changes in US corporate bond spreads. They concluded that if the risk-free rate and the stock index yields rise, the credit spreads will show a significant downward trend. Guha and Hiris (2002) analyzed how the economic cycle affects changes in corporate bond spreads in the United States. The results of the study showed that the relationship between the credit spreads and economic cycles is negative. When the economy is in a recession, credit spreads widen, and when the economy is in an expansion period, credit spreads will fall.

\section{Data, Methodology and Results}

\subsection{Data}

The purpose of this article is to study the extent to which the above variables affect credit spreads. Therefore, in this section we will describe data representing credit spreads and explanatory variables, and the monthly data of the US credit spread is from January 1990 to December 2018.

1) Credit spreads. The corporate bond data are collected from the Federal Reserve Bank of St. Louis distributed by Moody's Investor Services. We use only the Aaa and Baa yields, and the date we used for the analysis was monthly data from January 1990 to December 2018. The analyzed data is obtained by calculating the average of the daily data for each month, and the data is composed of non-seasonally adjusted corporate bonds with maturities of at least 20 years. When the bond is less than 20 years to the maturity date or the credit rating changes, the bond will be removed from the index. According to Moody's credit rating guidelines, Aaa bonds are considered to be bonds with the highest credit rating and bonds with lowest investment risk. Baa bonds are considered medium-weight bonds with certain risks and lack of good investment quality. Therefore we define the credit spreads as the Baa yields minus the Aaa yields.

The reason for choosing the Moody's Aaa and Baa corporate bond date is that Moody's index is made up of the yield of different bonds at a particular rating level. Therefore, the index represents the aggregate yield of return of a combination of individual bonds. This paper is focused on the aggregate variables rather than the individual firms, so Moody's corporate bond data looks more suitable as the choice for analyzing credit spreads.

2) Treasury rate level. We use the 10-year government bond series (code: GS10) as the risk free rate. The data is extracted from the Federal Reserve System and is composed of the average data of each month's business day yields. The data we use is from January 1990 to December 2018. The reason we chose the 10-year Treasury constant maturity rate is that it has a relatively long historical data and all data is available. Data on the 20 -year Treasury bond rate are not available from 1987 to 1992 . Moreover, many empirical analyses of credit 
spreads have chosen the 10-year Treasury bond rate as risk free rate, just like Morris, Neal and Rolph (1998), Collin-Dufresn et al. (2001), Kalimipalli, Nayak and Perez (2013) and so on.

3) Slope of yield curve. Merton (1974) concluded that the slope of yield curve and the level of yield curve are significant factors in determining the dynamic of term structure of interest rate. We define the slope of the yield curve as the difference between the 10-year yield and the 2 month Treasury bill rate. We will take the slope of the yield curve to represent the expected future short-term interest rate, and it can also be used as a factor representing the economic environment.

4) Industrial production index. Industrial production index is also obtained from the Federal Reserve System from January 1990 to December 2018, and it can be used as an indicator to measure the economic environment.

5) Volatility. VIX index is obtained from the Chicago Board of Exchange as monthly data. VIX represents market expectations for volatility in stock index option prices. This data is only available from January 1990, so it limits the amount of sample data analyzed in this article. If we can get more years of data, it may include many different business cycles, therefore we can expand the time frame of the study so that we can get more accurate results.

\subsection{Research Methodology}

In this paper, we mainly explore the impact of the industrial production index, risk free rate, stock market volatility and the slope of yield curve on the corporate bond spread. It mainly includes Baa corporate bond spreads, industrial production index, 10 year Treasury bond interest rate, VIX index and the slope of yield curve. The above data are all macro data. First, we just do a conventional time series regression, and the estimate regression is as follows:

$$
\mathrm{CS}_{t}=\alpha+\beta_{1} \mathrm{VIX}_{t}+\beta_{2} \mathrm{SLOPE}_{t}+\beta_{3} \mathrm{INDPRO}_{t}+\beta_{4} \mathrm{GS} 10_{t}+\varepsilon_{t}
$$

From the regression, we can know the significance level of the four variables, and we can have a general understanding of the positive and negative effects of the explanatory variables on the explained variables.

Then, we need to test the stationary of all the variables. This paper uses Augmented Dickey Fuller (ADF) tests to analyze the stationary.

H0: There is at least one unit root.

H1: No unit root.

Considering that the time series may also contain constant terms and trend terms, the $\mathrm{ADF}$ test has the following three forms:

$$
\begin{gathered}
\Delta y_{t}=\eta y_{t-1}+\sum_{i=1}^{p-1} \beta_{i} \Delta y_{t-i}+u_{i}, t=1,2, \cdots, T \\
\Delta y_{t}=\eta y_{t-1}+\alpha+\sum_{i=1}^{p-1} \beta_{i} \Delta y_{t-i}+u_{i}, t=1,2, \cdots, T \\
\Delta y_{t}=\eta y_{t-1}+\alpha+\delta t+\sum_{i=1}^{p-1} \beta_{i} \Delta y_{t-i}+u_{i}, t=1,2, \cdots, T
\end{gathered}
$$

In the formula $u_{i}$ is a random disturbance term. The ADF test was performed 
in Eviews 10.0, and the lag order was determined using the AIC criterion. If the test results show that the null hypothesis is rejected, the sequence y does not have a unit root, which means that all the variables are stationary. If the test results show that the null hypothesis is accepted, the original sequence needs to be differentially processed, when each variable becomes stationary after the difference, the process stops. The method can determine the single order of the sequence and use this result to determine the method to be used next.

The third estimator used in the analysis is the Cointegration. We use the Cointegration to analyze the impact of the risk free rate, the slope of yield curve, industrial production index and the VIX index on credit spreads in the long run.

Then we constructed a vector autoregressive (VAR) model. VAR is a very common model used to analyze dynamic relationships between time series variables. According to the properties of the VAR model, each variable in the model can be explained by its own lagged values and the lagged values of other variables (Enders, 1995).

The VAR model analyzes the statistical properties of the data. The VAR model often used to predict the relationship between the variables in the short run, and the impulse response function and variance decomposition are established based on the VAR model. The VAR model constructs the model by the lagged value of the endogenous variable.

$$
y_{t}=\Phi_{1} y_{t-1}+\cdots+\Phi_{p} y_{t-p}+H x_{t}+\varepsilon_{t}, t=1,2, \cdots, T
$$

In order to better estimate the causal relationship between variables, this paper uses the method of testing causality in econometrics. The Granger causality test examines the sequence of changes between variables, according to the method of testing causality in econometrics. Then by constructing impulse response functions, we analyze the short-term dynamic effects of risk free interest rates, slopes of yield curves, industrial production index and stock market volatility on credit spreads. Finally, we analyze the extent to which the four variables used in this paper can explain the error variance of bond spreads. Variance decomposition is very helpful in analyzing the contribution of the four variables to the residual term of the credit spread.

\subsection{Empirical Results}

\subsubsection{Correlation Analysis}

Table 1 is the correlation analysis of credit spread with VIX, INDPRO, GS10 and SLOPE. The results show that the correlation coefficients of CS with VIX, INDPRO, GS10 and SLOPE are $0.622,-0.129,0.358,-0.300$ respectively, which have significant statistical significance. This shows that there is a significant negative correlation among the credit spread with the industrial production index and the slope of yield curve, and there is a significant positive relationship between the corporate bond spread with the yield of 10 year Treasury bond and the VIX index. When the industrial production index and the slope of yield curve increase, the corporate bond spreads will decrease. When the yield of 10 
year Treasury bond and the VIX index increase, the corporate bond spreads will increase. The results of this regression look the same as we expected from theory. In the expectation, we assume that the risk free rate and the equity volatility are positive with the credit spreads, and the slope of yield curve and the business cycle are negative with the credit spreads.

\subsubsection{ADF Test}

Table 2 shows the results of ADF test on the horizontal values of the industrial production index, the yield of 10 years Treasury bond, VIX index and the slope of yield curve, and their first-order differences. The result of the ADF test shows that the series of industrial production index, 10-year Treasury bond rate and slope of yield curve are non-stationary in levels, but the credit spreads and VIX index are stationary in levels, and the first-order differential variables credit spreads, industrial production index, 10 year Treasury bond rate, the slope of yield curve and the VIX index have passed the corresponding ADF test, which indicates that in the test of the unit roots of the variables analyzed in this paper, their first order difference is stationary. It can be seen from the above analysis that DCS I(1), DINDPRO I(1), DGS10 I(1), DVIX I(1), DSLOPE I(1) are all single sequence, which is a stationary sequence, can be used for subsequent analysis to explore the direction and magnitude of the impacts of the yield curve slope, 10 year Treasury bond yield, VIX index and industrial production index on the Baa corporate bond spreads.

Table 1. Correlation analysis.

\begin{tabular}{cccccc}
\hline & CS & VIX & INDPRO & GS10 & SLOPE \\
\hline CS & 1.000 & 0.622 & -0.129 & 0.358 & -0.300 \\
VIX & 0.622 & 1.000 & -0.011 & 0.122 & -0.021 \\
INDPRO & -0.129 & -0.011 & 1.000 & -0.014 & -0.836 \\
GS10 & 0.358 & 0.122 & -0.014 & 1.000 & -0.340 \\
SLOPE & -0.300 & -0.021 & -0.836 & -0.340 & 1.000 \\
\hline
\end{tabular}

Table 2. Augmented dickey fuller tests.

\begin{tabular}{ccccc}
\hline & & ADF & $5 \%$ critical value & $p$ \\
\hline CS & $(\mathrm{C}, 0,1)$ & -4.081736 & -2.869677 & 0.0012 \\
INDPRO & $(\mathrm{C}, \mathrm{T}, 3)$ & -2.140683 & -2.871029 & 0.2290 \\
GS10 & $(\mathrm{C}, \mathrm{T}, 4)$ & -2.014745 & -2.869677 & 0.2805 \\
VIX & $(\mathrm{C}, 0,0)$ & -4.247841 & -2.869653 & 0.0006 \\
SLOPE & $(\mathrm{C}, 0,1)$ & -2.459724 & -2.871029 & 0.1265 \\
DCS $^{*}$ & $(\mathrm{C}, 0,0)$ & -23.81119 & -2.869677 & 0.0000 \\
DINDPRO $^{*}$ & $(\mathrm{C}, 0,0)$ & -4.486157 & -2.871029 & 0.0003 \\
DGS10 $^{*}$ & $(\mathrm{C}, 0,0)$ & -14.26482 & -2.869677 & 0.0000 \\
DVIX $^{*}$ & $(\mathrm{C}, 0,0)$ & -15.07556 & -2.869701 & 0.0000 \\
DSLOPE $^{*}$ & $(\mathrm{C}, 0,0)$ & -4.433300 & -2.871029 & 0.0003 \\
\hline
\end{tabular}




\subsubsection{Cointegration Analysis}

Through the above test, it can be known that credit spreads, VIX index, industrial production index, yield curve slope and 10-year Treasury bond rate are stationary in the case of first-order difference. If the above variables are all stationary, the CS, VIX, INDPRO, SLOPE, and GS10 are co-integrated. The cointegration analysis includes two test methods, which are the EG two-step test and the Johansen cointegration analysis. Since this paper has many independent variables, thus the Johansen analysis is selected for testing. Before using Johansen for testing, we need to determine the existence of the cointegration relationship.

From the results in Table 3, the maximal eigenvalue statistic and the trace statistic in the cointegration analysis show that there is a long-term stationary cointegration relationship between CS with SLOPE, VIX, INDPRO, and GS10 at a given $5 \%$ significance level.

$$
\mathrm{CS}=-0.9037 * \mathrm{INDPRO}+4.8259 * \mathrm{GS} 10+5.9524 * \mathrm{VIX}-4.7895 * \mathrm{SLOPE}+1.821
$$

Table 4 shows in the long run, the coefficients of different variables for the credit spreads. The risk free rate has a positive effect on the credit spreads, which means that when the risk free rate rises, the credit spread will also increase in the long run. This result supports the empirical analysis of Morris, Neale and Rolph (1998) previous empirical studies, but does not support Merton (1974) theoretical research. And this result is likely the previous regression before the cointegration.

We can also see from Table 4 that the impact of stock market volatility on credit spreads is positive. When the volatility of the stock market increases, the default risk of corporate bonds will increase, which will lead to an increase in credit spreads, and this result is consistent with our theoretical expectation.

Table 3. Johansen cointegration analysis.

\begin{tabular}{ccccc}
\hline Eigenvalue & Trace & 5\% Critical Value & Max & 5\% Critical Value \\
\hline 0.1366 & $125.0378^{\star}$ & 76.9728 & $50.5451^{\star}$ & 34.8059 \\
0.0985 & $74.4926^{*}$ & 54.0790 & $35.6747^{\star}$ & 28.5881 \\
0.0555 & $38.8180^{*}$ & 35.1928 & 19.6440 & 22.2996 \\
0.0337 & 19.1740 & 20.2618 & 11.7962 & 15.8921 \\
0.0212 & 7.3778 & 9.1645 & 7.3778 & 9.1645 \\
\hline
\end{tabular}

Note: The existence of the cointegration relationship is determined according to the minimum criteria of $\mathrm{AIC}$ and SIC. If there is a cointegration relationship, it is represented by ${ }^{*}$ in this paper.

Table 4. Long run cointegration regression.

\begin{tabular}{cccccc}
\hline CS & VIX & INDPRO & SLOPE & GS10 & C \\
\hline \multirow{2}{*}{1.000000} & -5.9524 & 0.9037 & 4.7895 & -4.8259 & -1.821 \\
& $(2.5565)$ & $(0.5142)$ & $(2.5239)$ & $(2.1170)$ & $(0.268)$ \\
\hline
\end{tabular}


The coefficient of industrial production index is consistent with the expected estimation. The increase in industrial production means that the economic environment is improving, the default risk of corporate bonds is reduced, and the leverage ratio is falling, so when industrial production increases, the credit spread will decrease, and the result is consistent with Davies (2007) empirical analysis.

Finally, Table 4 also shows that there is a negative relationship between the slope of the yield curve and the credit spreads, and this is also the same with the expected estimation. According to the term structure theory of interest rates, the slope reflects the future spot rate on the interest rate yield curve. If the slope of the yield curve increases, it indicates that the economy is improving, interest rates will rise in the future, and credit spreads will fall. Conversely, if the slope of the bond yield curve becomes smaller, it indicates that the economy is weakening, interest rates are lower in the future, and credit spreads are widening.

\subsubsection{Granger Casualty Test}

According to the above data analysis results, it is easy to know that in the long run, there is a stationary relationship between credit spread with industrial production index, 10 years Treasury bond yield, VIX index and the slope of yield curve. However, the cointegration analysis can only analyze the long run equilibrium relationship between the dependent variables and the independent variables, but the result does not indicate the causal relationship between variables. This article will estimate the casual relationship between the industrial production index, 10 year Treasury bond yield, VIX index, the slope of yield curve with the Baa credit spreads by using the Granger causality test. The Granger causality test examines the sequence of changes between variables, according to the method of testing causality in econometrics. The test is carried out and the test results are shown in Table 5.

According to the results of the above table, it can be known that in the case of the lag 4 , at the significance level of 0.05 , the test result shows that INDPRO and GS10 are the Granger cause of CS, and CS is also the Granger cause of the two variables. It indicates that the change of the two variables will cause the change of credit spreads, and the change of credit spreads will also cause the change of the two variables. The above results show that the two variables and the corporate bond spread are mutually Granger causality in the case of the optimal lag period. We also see that in the case of lag 4 , at the significance level of 0.05 , the test results show that the slope of yield curve and equity market volatility are the Granger cause of credit spread, but credit spread is not the Granger cause of the slope of yield curve and equity market volatility. This means that the change of the yield curve slope and stock market volatility will cause credit spread change, however the credit spread change will not cause the change of the two variables. The above results show that in the case of the best lag period, the slope of yield curve and the VIX index are the Granger causality of the credit spreads. 
Table 5. Credit spread Grander Casualty test.

\begin{tabular}{cccc}
\hline Lags & Null hypothesis & F-value & prob \\
\hline 4 & DVIX does not Granger Cause DCS & 9.72555 & 0.000 \\
4 & DCS does not Granger Cause DVIX & 0.43506 & 0.6476 \\
4 & DINDPRO does not Granger Cause DCS & 3.34618 & 0.0473 \\
4 & DCS does not Granger Cause DINDPRO & 3.60759 & 0.0282 \\
4 & DSLOPE does not Granger Cause DCS & 4.10326 & 0.0321 \\
4 & DCS does not Granger Cause DSLOPE & 2.09378 & 0.1248 \\
4 & DGS10 does not Granger Cause DCS & 4.75376 & 0.0218 \\
4 & DCS does not Granger Cause DGS10 & 6.79781 & 0.0013 \\
\hline
\end{tabular}

\subsubsection{The Vector Autoregressive Model}

In this paper, we determine the lag order based on the minimum criteria for LR, HQ, SC, FPE, and AIC and the value of each lag period are used. The minimum value of the lag period is represented by ${ }^{*}$, and Table 5 is the selection index in the optimal lag period. The best lag order is chosen (Table 6).

According to the minimum principle of LR, HQ, SC, FPE and AIC, the results show that the reasonable order of LR, FPE and AIC is 4th order, so the order of the credit spread VAR model is 4 th order.

1) Unit root test

According to the test results of the VAR model, it can be known that the established VAR model is reasonable, but we need to know whether the VAR model is stationary. In order to visually display this stationary, the unit root is generally used. Intuitive expression of the root map, if all the points are in the unit circle, indicating that the established VAR model is stationary, otherwise the VAR model is non-stationary, thus the established impulse response function and variance decomposition are unreasonable. We use Eviews10.0 to make the unit circles which are as follows:

From Figure 1, we can know that the unit roots of the VAR model are all in the unit circle which implies that the VAR model is stationary.

2) Impulse Response Function of the VAR Model

The impulse response function is to analyze the dynamic influence of an independent variable or other variables on the system when the model is subjected to a certain impulse. Based on the VAR model, we give these variables a positive impulse and then observe the impact on credit spreads. We use Eviews10.0 to make SLOPE, VIX, INDPRO, GS10 to credit spread impulse response function, the results are shown in the following figures, the horizontal axis represents the number of retrospective periods (unit: monthly), the vertical axis represents the change of the corporate bond spread, and the solid line represents the trend and direction of the impulse response function, reflecting the response of the corporate bond spread and the corresponding influencing factors. The dashed line indicates the deviation band formed by the positive and negative two standard 
Inverse Roots of AR Characteristic Polynomial

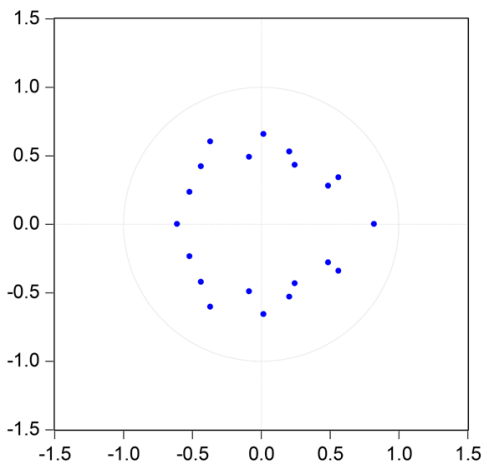

Figure 1. The unit circle.

Table 6. VAR model lag order test result.

\begin{tabular}{ccccccc}
\hline Lag & LogL & LR & FPE & AIC & SC & HQ \\
\hline 0 & -3035.737 & NA & 34.4965 & 17.7302 & 17.7862 & 17.7525 \\
1 & -2937.866 & 192.3177 & 22.5553 & 17.3053 & $17.6410^{\star}$ & 17.4390 \\
2 & -2889.041 & 94.5174 & 19.6317 & 17.1664 & 17.7818 & 17.4115 \\
3 & -2836.909 & 99.4010 & 16.7629 & 17.0082 & 17.9033 & $17.3648^{\star}$ \\
4 & -2807.363 & $55.4729^{*}$ & $16.3314^{*}$ & $16.9817^{*}$ & 18.1565 & 17.4497 \\
\hline
\end{tabular}

deviations of the impulse response function. This paper uses the impulse response function to verify the dynamic utility between the credit spread and SLOPE, VIX, INDPRO, GS10.

As can be seen from the above Figure 2, when the industrial production index has a positive impact, the impact on the corporate bond spread is obvious. In the first period, the impact is positive, and then the impact decreases quickly. In the third period, the negative maximum value is reached, then it rises and slowly converges, and in the eighth period, it converges to zero. During the graphic observation period, the impact of the industrial index on the credit spread in the short term was negative for most of the period, and this trend starts from the second period and continued to the tenth period. It shows that the impact of the industrial production index on the spread of corporate bonds is negative, and the finding is the same as Davies (2007). The impulse results show that when the industrial production index increases, the corporate bond spread becomes narrow. This means that both in the long run and short run, the relationship between the industrial production index and the credit spreads is negative.

The figures also show that after giving a positive impulse on the risk free rate, the impact on the credit spreads is very significant. In the first period, the impact was small, the impact was positive, then decreased, and decreased to a negative maximum in the third period, and then rising gradually converges to zero in the sixth period. It can be seen that the impact of the risk free rate on the credit spreads remains basically negative in the short run. However, in the long run, the 


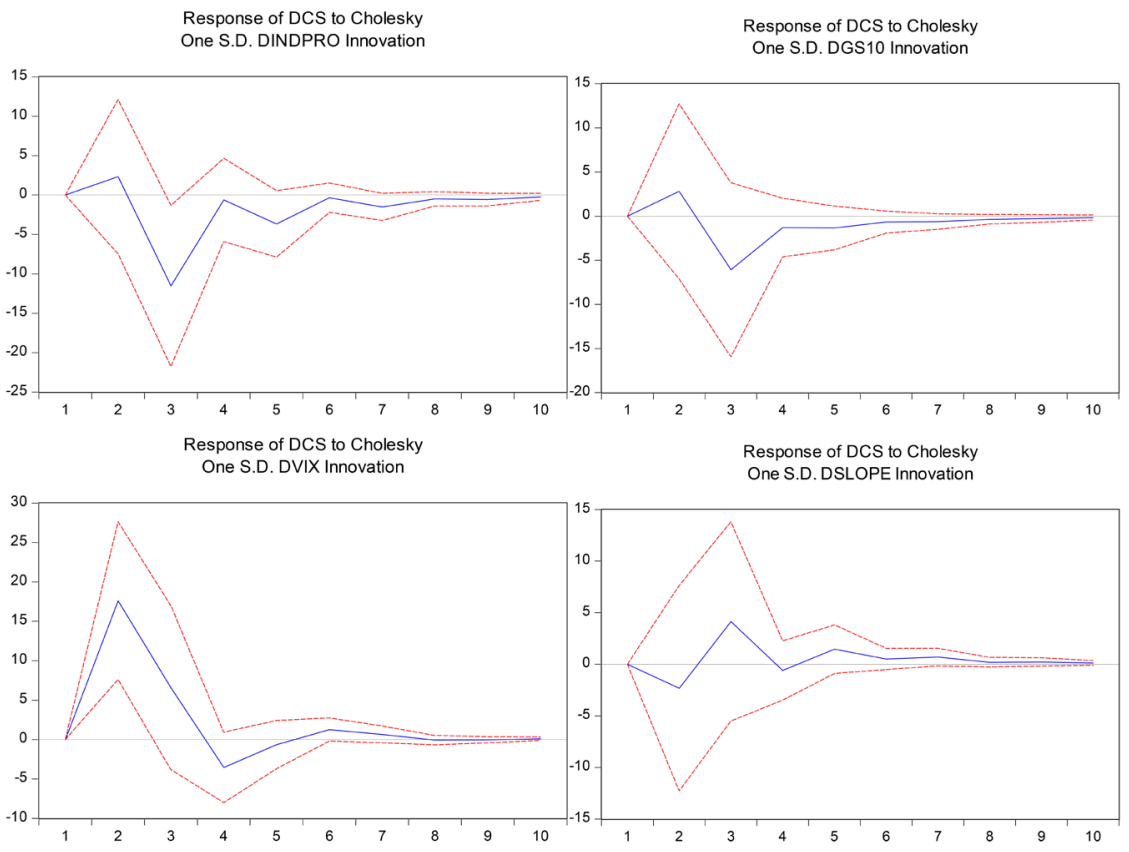

Figure 2. The impulse function of corporate bond spread.

risk free rate has a positive impact on the credit spreads, and the empirical results support previous literatures reported by Davies (2007) and Morris, Neale and Rolph (1998). This implies that in the short run, when the risk free rate rises, the credit spreads will decrease, and in the long run, the credit spreads will increase.

Moreover, when the VIX is impacted, the impact on the corporate bond spread is very obvious, reaching the negative maximum in the second period, and then decreases. The fourth period reaches the negative maximum, but the maximum is small, and then begins to produce certain fluctuations, which converge to zero in the eighth period. It shows that the stock volatility has a significant negative impact on the credit spread. Then the impact rises rapidly and produces a positive impact, then falls to a negative impact, and finally converges to a value of zero. It shows that the impact of stock volatility on the spread of Baa corporate bonds in the short term is positive. This effect lasts for a long time and the impact is relatively stable. By comparison, the impact of VIX on credit spreads in the short term is greater than the impact of industrial price index and 10 year Treasury bond rate on credit spreads.

When the slope of yield curve has a positive impact, the impact of Baa corporate bond spreads is not very obvious. In the second period, the impact reaches the negative maximum, then rises rapidly, and reaches the positive maximum in the third period. It began to decline and gradually converges to zero after the seventh period. Explain that the impact of slope on credit spreads is not very stable, but the general impact is positive, and the growth of Slope will cause positive fluctuations in credit spreads. This result is consistent with Collin-Dufresn et al. (2001) and Davies (2007), but does not support the research of Avramov, Jostova, 
\& Philipov (2007). We find that the impact of the slope of yield curve is not very significant, and the result shows that in the long run and in the short run the effects of the yield curve slope is opposite. The slope of the yield curve is not a pure indicator of macroeconomic operation. It seems like a reflection of macroeconomic operations, so its impact on credit spreads is not significant enough and the direction is not clear.

3) Variance decomposition

Since the VAR model is a model for studying the influence of endogenous variables on other variables, the industrial production index, VIX, 10 years Treasury bond rate, and the slope of yield curve are analyzed using the impulse function. In order to analyze the magnitude of the impact of the dynamic model of corporate bond spread, the following will analyze the industrial production index, the 10 years Treasury bond rate, the VIX index, and the slope of yield curve using the Cholesky variance decomposition. The results obtained by Eviews 10.0 for variance decomposition are as follows, where the horizontal axis represents the lag, the vertical axis represents the industrial index, the 10 years Treasury bond rate, the VIX index, the slope of yield curve and the contribution rate of the change of corporate bond spread (unit: percentage) (Table 7).

Credit spreads are mainly affected by credit spreads themselves, industrial production index, stock volatility, 10 years Treasury bond rate and the slope of yield curve. The impact of credit spreads themselves has remained above $87 \%$ in the tenth period. The impact of 10 years Treasury bond rate on credit spreads reached a maximum of $0.7 \%$ in the first ten periods, indicating that the impact of 10 years Treasury bond is small; the impact of industrial production index on credit spreads has increased over time, reaching about $4 \%$ in the tenth period, and the impact of stock volatility on credit spreads reached a maximum of $7.6022 \%$ in the 10th period, and the maximum impact of the slope of yield curve on credit spreads was $0.8404 \%$. It shows that the current changes in credit spreads in the short term are mainly affected by their own and stock volatility, and are less affected by the industrial production index, the 10 years Treasury bond rate, and the slope of yield curve.

Table 7. Variance decomposition result of corporate bond spreads.

\begin{tabular}{ccccccc}
\hline Lag & S.E. & DCS & DVIX & DINDPRO & DSLOPE & DGS10 \\
\hline 1 & 89.4856 & 100.0000 & 0.0000 & 0.0000 & 0.0000 & 0.0000 \\
2 & 96.4445 & 95.3038 & 4.5053 & 0.0087 & 0.0466 & 0.1356 \\
3 & 99.0541 & 91.7107 & 4.7946 & 2.9934 & 0.2705 & 0.2308 \\
4 & 100.9216 & 89.4688 & 6.7369 & 2.8837 & 0.3245 & 0.5861 \\
5 & 101.3760 & 88.6876 & 6.7033 & 3.1704 & 0.7927 & 0.6460 \\
6 & 101.6518 & 88.2155 & 7.0299 & 3.2843 & 0.7928 & 0.6774 \\
7 & 102.0277 & 87.6487 & 7.4479 & 3.4012 & 0.7940 & 0.7083 \\
8 & 102.2768 & 87.2256 & 7.5445 & 3.6893 & 0.8203 & 0.7203 \\
9 & 102.3389 & 87.1342 & 7.6044 & 3.7040 & 0.8303 & 0.7272 \\
10 & 102.3532 & 87.1219 & 7.6022 & 3.7083 & 0.8404 & 0.7271 \\
\hline
\end{tabular}




\section{Conclusion}

This paper analyzes the credit spreads of the Baa corporate bond in the US using a 28-year history. When researching individual company credit spreads, it is more likely that individual company historical data is difficult to find, but the use of macroeconomic variables in this paper can effectively avoid this problem. Moreover, economists have done a lot of microcosmic research on US credit spreads, but the literature from the macroeconomic point of view is relatively few. Therefore, the innovation of this study is to find out the determinants of credit spreads in the US in the macroeconomic variables. This article examines the impact of risk free rates, the slope of yield curve, the stock market volatility, and the economic environment on Baa corporate bond spreads from January 1990 to December 2018 by employing a VAR model. This paper uses cointegration to model the time-series of the credit spread with the interest rates, VIX index, industrial production index and the stock market volatility. The result shows that the impacts of the industrial production index and the slope of yield curve on the Baa credit spreads are negative, and the impacts of 10 years Treasury bond rate and the stock market volatility on the credit spreads are positive in the long run. Then this paper analyzes the short-run dynamic relationship between these variables by constructing a VAR model, analyzes the impulse response function established according to the VAR model, and observes the impact of the risk-free interest rate, economic environment, stock market volatility and the slope of the yield curve on the credit spread of Baa. Through the ADF test, the results show that the industrial production index, the risk-free interest rate and the slope of the yield curve are non-stationary time series. When the first-order difference is made for all variables, they are all stationary. And then VAR is used to derive the short-term relationship between variables, and then the impulse function and variance decomposition are used to derive the dynamic relationship of the variables. The results show that in the short-term dynamic relationship, the impact of the industrial production index and the 10-year Treasury bond interest rate are negative for the credit spreads, and the slope of yield curve and stock market volatility are positive for the BAA credit spreads. The impact of the slope of yield curve for the credit spreads is not very obvious, and in the long run and in the short run, the effects of the yield slope curve are opposite.

The limitation of this article is that the data in this article is entirely from the United States. For the time being, economists have done a lot of research on US credit spreads and there are many related literatures. More and more researchers hope to study the relevant content of new opportunities in the global market. Especially now that the corporate bond market is booming in Europe, a valuation framework to measure credit risk needs to emerge. If we try to draw conclusions about the credit spreads in the European market from the conclusions of this paper, we can only get an approximation, and we can't accurately estimate the behaviour of credit spreads in European markets. 
This analysis focus on the Baa corporate bond spreads, even if bond yields of different credit ratings are affected by the aggregate economic variables, their degree of response to the same variable will vary. Therefore, the suggestion is that the same variable may have different impact on the corporate bond spreads of different credit ratings, so the study is left for future research.

\section{Conflicts of Interest}

The author declares no conflicts of interest regarding the publication of this paper.

\section{References}

Anderson, R. W., \& Sundaresan, S. (1996). Design and Valuation of Debt Contracts. Review of Financial Studies, 9, 37-68. https://doi.org/10.1093/rfs/9.1.37

Avramov, D., Jostova, G., \& Philipov, A. (2007). Understanding Corporate Credit Risk Changes. Financial Analysts Journal, 63, 90-105.

https://doi.org/10.2469/faj.v63.n2.4525

Bevan, A., \& Garzarelli, F. (2000). Corporate Bond Spreads and the Business Cycle: Introducing GS-SPREAD. The Journal of Fixed Income, 9, 8-18. https://doi.org/10.3905/jfi.2000.319249

Campbell, J., \& Taksler, G. (2003). Equity Volatility and Corporate Bond Yields. Journal of Finance, 58, 2321-2349. https://doi.org/10.1046/j.1540-6261.2003.00607.x

Collin-Dufresn, P., Goldstein, R. S., \& Martin, J. S. (2001). The Determinants of Credit Spread Changes. The Journal of Finance, 56, 2177-2207.

https://doi.org/10.1111/0022-1082.00402

Davies, A. (2004). Credit Spread Modelling with Regime Switching Techniques. Journal of Fixed Income, 14, 36-48. https://doi.org/10.3905/jfi.2004.461450

Davies, A. (2007). Credit Spread Determinants: An 85 Year Perspective. Journal of Financial Markets, 11, 180-197. https://doi.org/10.1016/j.finmar.2007.10.002

Duffee, G. R. (1998). The Relation between Treasury Yields and Corporate Bond Yield Spreads. The Journal of Finance, 53, 2225-2241.

https://doi.org/10.1111/0022-1082.00089

Elton, E. J., Gruber, M. J., Agrawal, D., \& Mann, C. (2001). Explaining the Rate Spread on Corporate Bonds. The Journal of Finance, 56, 247-277. https://doi.org/10.1111/0022-1082.00324

Enders, W. (1995). Applied Econometric Time Series. New York: Wiley.

Eom, Y., Helwege, J., \& Huang, J. (2004). Structural Models of Corporate Bond Pricing: An Empirical Analysis. Review of Financial Studies, 17, 499-544. https://doi.org/10.1093/rfs/hhg053

Fama, E. F., \& French, K. R. (1989). Business Conditions and Expected Returns on Stocks and Bonds. Journal of Financial Economics, 25, 23-49. https://doi.org/10.1016/0304-405X(89)90095-0

Guha, D., \& Hiris, L. (2002). The Aggregate Credit Spread and the Business Cycle. International Review of Financial Analysis, 11, 219-227. https://doi.org/10.1016/S1057-5219(02)00075-3

Kalimipalli, M., Nayak, S., \& Perez, M. F. (2013). Dynamic Effects of Idiosyncratic Volatility and Liquidity on Corporate Bond Spreads. Journal of Banking and Finance, 37, 
2969-2990. https://doi.org/10.1016/j.jbankfin.2013.04.019

Krishnan, C. N. V., Ritchken, P. H., \& Thomson, J. B. (2010). Predicting Credit Spreads. Journal of Financial Intermediation, 19, 529-563. https://doi.org/10.1016/j.jfi.2009.02.004

Longstaff, F. A., \& Schwartz, E. S. (1995). A Simple Approach to Valuing Risky Fixed and Floating Rate Debt. The Journal of Finance, 50, 789-819. https://doi.org/10.1111/j.1540-6261.1995.tb04037.x

Manzoni, K. (2002). Modeling Credit Spreads. International Review of Financial Analysis, 11, 183-218. https://doi.org/10.1016/S1057-5219(02)00074-1

Merton, R. C. (1974). On the Pricing of Corporate Debt: The Risk Structure of Interest Rates. The Journal of Finance, 29, 449-470. https://doi.org/10.1111/j.1540-6261.1974.tb03058.x

Morris, C., Neal, R., \& Rolph, D. (1998). Credit Spreads and Interest Rates: A Cointegration Approach (No. 98-08). Federal Reserve Bank of Kansas City.

Pedrosa, M., \& Roll, R. (1998). Systematic Risk in Corporate Bond Credit Spreads. Journal of Fixed Income, 8, 7-26. https://doi.org/10.3905/jfi.1998.408249

Simon, G., \& Egon, Z. (2012). Credit Spreads and Business Cycle Fluctuations. The American Economic Review, 102, 1692-1720. https://doi.org/10.1257/aer.102.4.1692

Tao-Hsien, D. K., \& Kenneth, K. (2005). On the Importance of Systematic Risk Factors in Explaining the Cross-Section of Corporate Bond Yield Spreads. Journal of Banking \& Finance, 29, 3141-3158. https://doi.org/10.1016/j.jbankfin.2005.01.007 